\title{
Non-parametric and parametric analysis of runoff in Satluj River Basin, Himachal Pradesh, India
}

\author{
Sandeep Kumar ${ }^{1}$, Santosh ${ }^{2}$ \\ ${ }^{1}$ Department of Environment Studies, Panjab University, Chandigarh, India. \\ ${ }^{2}$ Department of Environmental Sciences, MDU, Rohtak (Haryana), India. \\ E-mail address: ssheoran81@yahoo.co.in \\ ssheoran84@gmail.com
}

\begin{abstract}
Keywords: Mann-Kendall test, Regression, Runoff, Satluj River Basin, Trend analysis.
\end{abstract}
\begin{abstract}
Testing the significance of observed trends in hydrological time series has received a great attention recently, especially in connection with climate change. The changing pattern of runoff deserves urgent and systematic attention over a basin for planning, development, utilisation and management of water resources. Therefore, one large catchment i.e. Indian part of Satluj River Basin is selected for the present study. The daily data of runoff were converted to monthly and then computed to seasonal and annual series. The missing values in the data were computed by using average method. For better understanding of the observed trends, data were computed into standardised runoff indices (SDI). These standardised data series were plotted against time and the linear trends observed were represented graphically. The records of runoff were subjected to trend analysis by using both non-parametric (Mann-Kendall test) and parametric (linear regression analysis) procedures. Trend analysis results of runoff show that out of 8 annual trends $2(25 \%)$ are statistically insignificant increasing and $6(75 \%)$ are decreasing in nature where $2(25 \%)$ are statistically significant at $95 \%$ confidence level. Apart from annual, the changes were investigated for the four seasons: winter (December-March), pre-monsoon (April-June), monsoon (JulySeptember) and post-monsoon (October-November). The analysis of annual as well as seasonal runoff for the Satluj River Basin indicates significant changes from 1984 to 2010. There is a clear contrast in the runoff pattern of river between the high altitude mountainous region and the lower reaches where it changes as a result of contribution from rainfall, especially during monsoon season. Although the runoff at majority of stations showed decreasing trend, but very few are statistically significant. Such studies help us to resolve potential issues associated with availability of water for agriculture, industry, hydropower, domestic use etc.
\end{abstract}

\section{Introduction}

Climate change arising from anthropogenic driven emissions of greenhouse gases has emerged as one of the most important environmental issues in the last two decades. Information about impacts of climate change is required at global, regional and basin scales for a variety of purposes. The consequences of climate change on Indian sub-continent, especially the mountainous regions are poorly understood. The Himalayan region has large and intricate network of river systems which is reinforced by the snowmelt, glaciermelt and rainfall. Many of major rivers originating in this region have their upper catchments covered by snow/glacier. The altitude and climatic change induced precipitation variability are expected to play major role on runoff pattern. Increased temperature is expected to reduce average flow of snow-fed rivers of Himalayas, coupled with an increase in peak flows.

An understanding of the hydrological response of a river basin under changing climatic conditions will help to resolve potential issues associated with hydro-meteorological disasters and availability of water for agriculture, industry, hydropower, domestic use etc. The changing pattern of runoff deserves urgent and systematic attention over a basin which provides an insight view of historical trends. Therefore, information on trend analysis over a basin scale is of utmost importance for planning, development and utilisation of water resources. The assessment of hydro-climatic 
trends of river basin can provide a perspective assessment on catchment dynamics. Trend analysis has proved to be useful tool for effective water resources planning, design and management since trend detection of hydrological variables provides a useful information on the possibility of change in tendencies of the variables in future (Hamilton et al., 2001; Yue and Wang, 2004).

The intensive human activities, including reservoir construction, hydropower development and water abstraction have become more serious issues from the upper to the lower part of Himalayan Rivers' catchments. These have substantially changed the hydrology of the river. One of the most significant potential consequences of climate change may be alteration in regional hydrological cycle and river flow regimes. For this reason, it becomes very important to investigate the changes in the spatial and temporal pattern of runoff in order to improve water management strategies. Necessity of the hour is to concentrate on the studies, how the possible climate change will affect the intensity, temporal and spatial variability of runoff pattern in river basins. It became utmost important to study the impacts of climate change and its variability on changing the runoff pattern in river for designing regional and national long term developmental strategies which are supposed to be benign in nature i.e. sustainable.

Therefore, one large catchment (Satluj) is selected for the present study. Most of the flow in its upper mountain basin is derived from the melting of snow and glaciers. Climatic variability and change in precipitation pattern will affect the runoff in the river. The changes in the amount and seasonal distribution of precipitation have potentially serious implications for the hydrological regimes of catchment area. The nature of climate change and its impact on the hydrology of the Satluj River Basin have been studied inadequately because of inaccessibility, terrain ruggedness and sparse network of gauge stations. The present study tries to fill this vacuum by studying the impact of climate change on runoff pattern.

Testing the significance of observed trends in hydrological time series has received a great attention recently, especially in connection with the assessment of observed changes in the natural and human environment due to global warming. This is reflected by a huge number of studies carried out over the last three decades, dealing with the assessment of significance of trends in a variety of natural time series.

A river flow regime describes an average seasonal behaviour of flow and reflects the climatic and physiographic conditions in a basin. Differences in the regularity (stability) of the seasonal patterns reflect different dimensionality of the flow regimes which can change subject to changes in climate conditions. Under the influence of changing climatic conditions, a flow regime might destabilize and turn over to quite different seasonal patterns of high and low water, thus disturbing the established hydro-ecological conditions (Krasovskaia and Gottschalk, 2002). IPCC (2001b) draws attention to changes in the timing of stream flow caused by global warming.

An increasing trend in global streamflow has been variously attributed to global warming, land use, and a reduction in plant transpiration under higher $\mathrm{CO}_{2}$ levels (Krakauer and Fung, 2008). There are apparent trends in streamflow volume, both increases and decreases, in many rivers of the world. According to IPCC (2001a), climate change is likely to change streamflow volume, imposing significant stress on water resources. Burn et al. (2004) investigated trends in the streamflow series of the Liard River in northern Canada. Trends were investigated using the MannKendall test, with a serial correlation approach. Various reports indicate that climatic change is likely to increase runoff in higher latitude regions because of increased precipitation.

The increased temperature in winter is expected to lead earlier snowmelt events and a shift in runoff from the spring to late winter with a corresponding decrease in runoff in the summer period (Burn and Hag Elnur, 2002). Zhang et al. (2001) calculated trends for 11 hydro-metric variables for Canadian Catchments and found generally decreasing trends in flow volumes. Trends of precipitation and runoff in major Chinese rivers were calculated and compared in order to better quantify the hydrological processes and evaluate the role of human activities in changing river runoff. Runoff revealed the mixed response in various rivers i.e. increasing and decreasing trends (Xu et al., 2010). Loukas and Quick (1996) predicted an overall increase in annual runoff caused by increased temperature $\left(3.2\right.$ to $\left.3.8^{\circ} \mathrm{C}\right)$ and increased precipitation (14.9 to $\left.15.5 \%\right)$. 
Beyene et al. (2010) studied the potential impacts of climate change on the hydrology and water resources of the Nile River basin using a macro scale hydrology model. The river is expected to experience an increase in streamflow early in the study period (2010-2039), due to generally increased precipitation. Streamflow is expected to decline during mid (2040-2069) and late (20702099) century as a result of both precipitation declines and increased evaporative demand. There is increase in the ratio of rain to snowmelt contribution to runoff, an increase in winter runoff as a fraction of total annual runoff, an earlier and faster spring snowmelt, a shorter snowmelt season, a decrease in late spring and summer runoff as a fraction of total annual runoff (Gleick and Chalecki, 1999).

The runoff regime in snowmelt dominated river basins is most sensitive to temperature increases in snowfall season (Adam et al., 2009). The analysis indicated that the climate change is likely to change streamflow volume, as well as temporal distribution throughout the year over Asian region (IPCC, 2001b). The changes in the hydrological response of a basin will depend on the sources of runoff, climatic conditions, physical characteristics of the basin and the magnitude of projected climatic scenarios. Thus, basins located in different regions will experience different impact of the variability in the climate (Chiew et al., 1995). Cayan et al. (1993) studied the effect of precipitation, temperature and snow water content on streamflow using linear regression models. They reported a large difference in the lower and higher altitude basins because of changes in their runoff distribution and climatic regime. More than one-sixth of the world's population live in glacier or snowmelt-fed river basins and will be affected by the seasonal shift in streamflow, an increase in the ratio of winter to annual flows and possibly the reduction in low flows caused by decreased glacier extent or snow water storage.

The effect of climate change on streamflow varies regionally, largely due to projected changes in precipitation. Rising temperatures may cause snow to melt earlier and faster in the spring, shifting the timing and distribution of stream runoff (Barnett et al., 2005). Glacier-related changes in the river runoff usually increased from enhanced ice melt, while water yield will decrease in the long term. The combination of shifts in seasonality and changes in total runoff are likely to have consequences for future water availability, increasing the challenges for management of water resources originating in mountains (Viviroli et al., 2010) along with the problems associated with the increase in frequency and intensity of extreme hydro-meteorological events. The changes in river flows due to climate change depend on changes in the volume, timing and intensity of precipitation, snowmelt and whether precipitation falls as snow or rain (Chiew, 2007).

However, based on the yearly hydrographs of Satluj River, the following periods can be identified to estimate the contribution of various components (Bhutiyani et al., 2008):

- Winter runoff (largely base flow from sub-glacial melting and ground water storage), November to February.

- Spring runoff (base flow + seasonal snow melt), March to May.

- Monsoon runoff (base flow + monsoon rainfall + glacier melt), June to October.

Trend analysis over the historic record of runoff is very difficult for mountainous areas. In the Satluj River, the natural runoff pattern has been altered largely by dams or diversions which make it difficult to assess changes in the natural response of amount and timing of streamflow. The trend analysis of the runoff data of rivers in northwestern Himalayas, with reference to impact of climate change, is studied by Bhutiyani et al. (2008). Studies on Satluj River indicate an episodic variation in runoff in all three seasons on a longer time scale of about 82 years (1922-2004). Statistically significant decrease in the average annual and monsoon runoff; and insignificant increase in winter and spring runoff can be seen despite increasing temperature during all the seasons. Despite increasing temperature and average monsoon rainfall, there is decreasing runoff during winter and monsoon seasons in the post 1990 period which strongly indicates decreasing contribution of glaciers to the runoff i.e. gradual retreating.

The trends in several hydro-meteorological variables in the upper Indus River Basin (UIRB), Pakistan were examined. Increased winter temperatures are likely to increase streamflow in winter and spring (Khattak et al., 2011). With the increase of temperature, the glacier would melt gradually 
which results in increase of runoff. However, glaciermelt water would be exhausted due to continual glacier shrinkage, and the increased trend of runoff would slow down in future (Xu et al., 2011).

\section{STUDY AREA}

The Satluj River (Vedic name - Satudri and Sanskrit name - Shatadru), also known as the Langqên (Chinese) and Sutlej (Indian), is the principal and easternmost tributary of the Indus River system. The basin area falls in Lahaul \& Spiti, Kinnaur, Shimla, Kullu, Mandi, Solan and Bilaspur districts of Himachal Pradesh. The geographical limits of area lie between $30^{\circ} 45^{\prime} \mathrm{N}$ to $33^{\circ} 00^{\prime} \mathrm{N}$ latitudes and $76^{\circ} 15^{\prime} \mathrm{E}$ to $79^{\circ} 00^{\prime} \mathrm{E}$ longitudes in the western Himalayas (Figure 1). The total catchment area of Satluj River, from origin to Bhakra dam, is about 56,875 km $\mathrm{km}^{2}$ (21,960 Sq. miles). The upper part of river basin is considerably wider than the lower one. In Himachal Pradesh, Satluj Basin has catchment area of $20,398 \mathrm{Km}^{2}$ which is $30.7 \%$ of the total catchment area of river systems (SCST \& E, 2006). Indian part of river up to Bhakra Dam is elongated in shape and covers the part of outer (Shiwalik range), middle (Dhauladhar range) and greater Himalayas (Zaskar range).

Satluj River originates from the southern slopes of Kailash Mountains i.e. from Rakas Lake, near the Mansarovar Lake as Longcchen Khabab River at an elevation of about 4,572 $\mathrm{m}$ (15,000 ft), above msl. Total length of river is approximately $1,448 \mathrm{~km}(320 \mathrm{Km}$ in China, $758 \mathrm{Km}$ in India and $370 \mathrm{Km}$ in Pakistan). It enters India from East of Shipki La (altitude $-3,048 \mathrm{~m}$, above msl) after traversing a length of about $320 \mathrm{~km}$ (200 miles) in the Tibetan province of Nari Khorsam, through a narrow gorge in the Kinnaur district of Himachal Pradesh and flows in southwesterly direction. The river is supported by a number of mighty tributaries on either side. Main tributaries are Spiti, Baspa and Gambhar at Khab, Karchham and Kangri at an elevation of 2,600, 1,750 and $450 \mathrm{~m}$ above msl respectively. Near Rampur, it crosses the Dhauladhar range and then traverses through a series of successive Shiwalik ranges. Before leaving the Himachal Pradesh, it cuts a gorge in Naina Devi Dhar and mingles with the water of Govind Sagar Lake. It enters the plains of Punjab near Bhakra where Asia's one of the highest gravity multipurpose dam (Capacity to generate electricity $-1,325$ MW and height - $740 \mathrm{ft} / 225.55 \mathrm{~m}$ ) has been constructed. It finally drains into the main Indus River in Pakistan. 


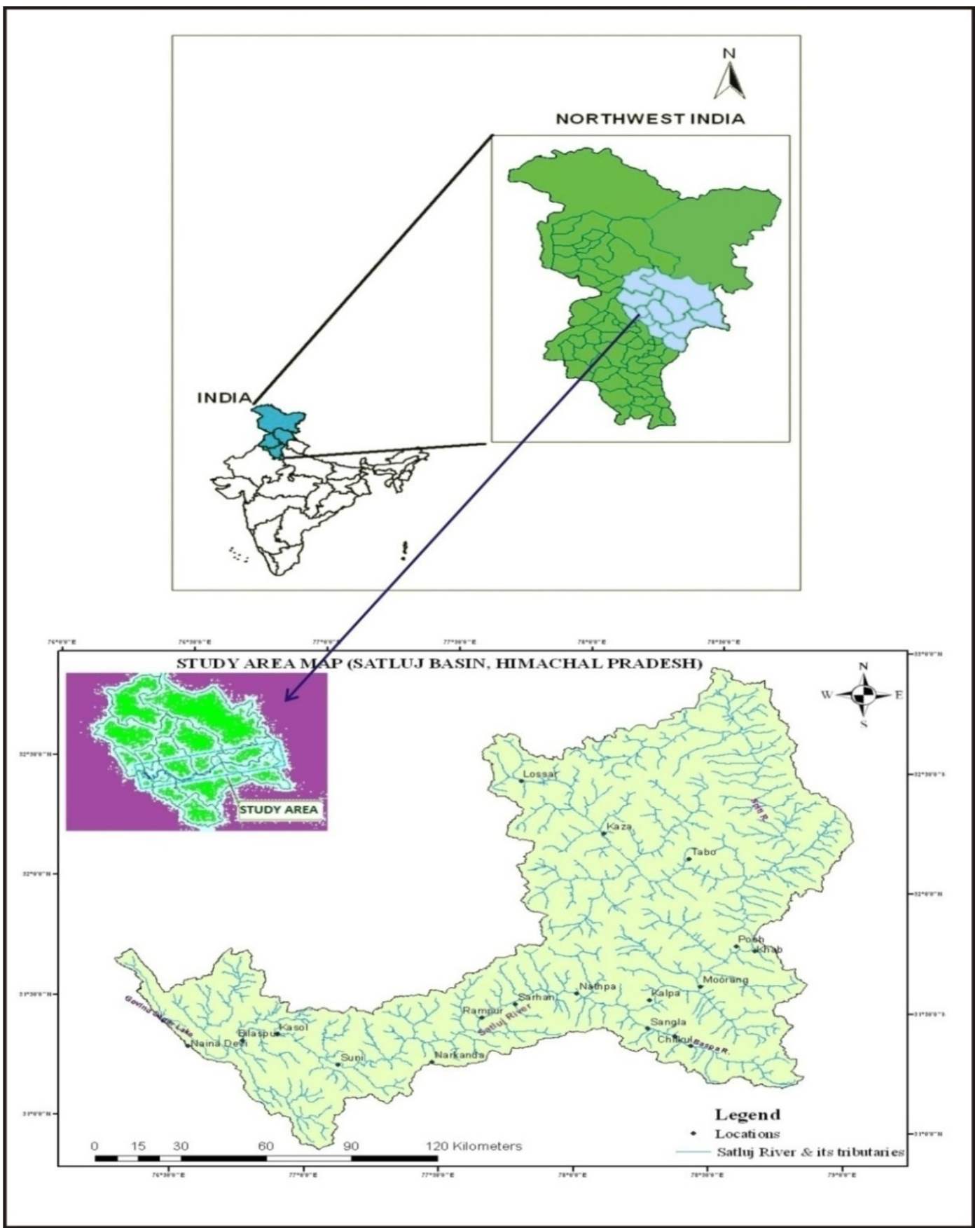

Figure 1. Schematic showing the study area map of Satluj River Basin upto Bhakra Dam, Himachal Pradesh.

Based on the amount of annual precipitation and the variation in temperature, the study area, from North to South, has been divided into three broad climatic zones (Figure 2). Each zone is characterised by its own peculiarities of climatic factors, geomorphic and topographic features (Gupta et al., 1994; Bartarya et al., 1996):

1. Semi-arid to arid temperate zone (Cold desert) - This zone lies in the upper Satluj Valley, upstream from Morang. Towards North of Morang, the cold desert conditions prevail which are characterised by very low monsoonal precipitation, high speed of cold winds and the precipitation generally occurs in the form of snowfall during winter season.

2. Sub-humid to humid temperate zone - This zone covers the middle Satluj Valley between the Wangtu and Morang. It is the transitional zone which receives low rainfall during the monsoon period and moderate to heavy snowfall in the higher reaches during winter.

3. Wet temperate or Monsoonal zone - It lies in the lower Satluj Valley downstream of Wangtu. This zone is under the great influence of monsoonal winds and receives heavy rainfall during rainy season from mid June to mid September. 


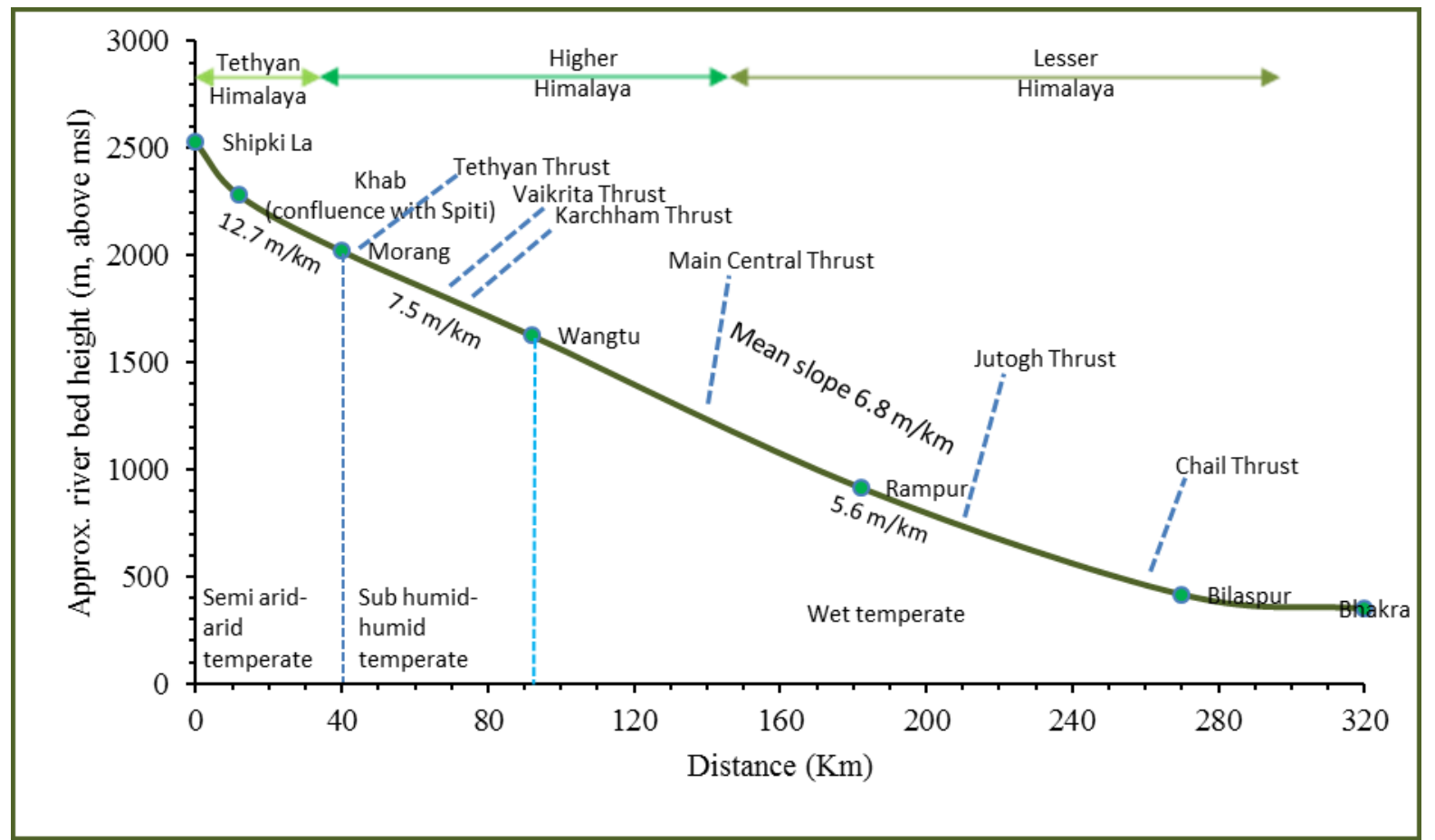

Figure 2. Longitudinal profile of Satluj River from Shipki La to Bhakra Dam. Three climatic zones are demarcated along with the major thrusts.

The fall of Satluj from its source to the plain areas is very uniform. A gross fall of $2,180 \mathrm{~m}$ is available in the river bed from Shipki La to Bhakra in a length of about $320 \mathrm{Km}$ (Figure 2). The altitude in the study area increases from West to East and South to North. Based on broad climatic conditions, the Satluj River Basin has following four seasons: Winter (December to March), Premonsoon (April to June), Monsoon (July to September), Post-monsoon (October, November).

\section{MATERIALS AND METHODS}

For the considered study area, records of runoff were subjected to trend analysis by MannKendall and regression coefficient test. In order to determine the degree and rate of change in climatic trends, long-term data sets are required. Burn and Elnur (2002) stated that a minimum record length of 25 years ensures validity of the trend results statistically. The present analytical study on the spatial and temporal trends is based on the available meteorological data from Bhakra Beas Management Board (BBMB), Nangal and Satluj Jal Vidyut Nigam Limited, Shimla. The trends were identified by investigating the time series of different observation stations distributed over the Indian part of Satluj River Basin. Paucity of long term data restricts the study. Data was scarce especially in the upper catchment area because of inadequate hydro-meteorological networks in the high altitude regions with rugged terrain and poor accessibility. The climatic and meteorological information had been started at Khab and Nathpa in 1990 but the long term data was available for the lower reaches of river. Runoff was measured in river along with various tributaries by area-velocity method as per IS: 1192:1981 standards and total monthly average was calculated at Govind Sagar lake.

In order to investigate trends in time series, observational records were prepared. The daily data were converted to monthly and then computed to seasonal and annual series. Annual runoff (Cumecs) was calculated as the mean of monthly data set. The missing values in the data were computed by using average method. To bring uniformity and facilitate comparison between the annual and seasonal responses, yearly standardised discherge indices (SDI) can be computed by subtracting the mean and dividing by the standard deviation of runoff data series. The SDI data series are then subjected to trend analysis by statistical techniques (Pant and Rupakumar, 1997; Shreshtha et al., 2000; Bhutiyani et al., 2008). These standardised time series data were plotted against time and the linear trends observed were represented graphically. The linear trend values, 
represented by the slope of a simple least square regression line with time as independent variable gave the magnitude of rise or fall. Apart from annual, the changes were investigated for the four seasons: winter (December-March), pre-monsoon (April-June), monsoon (July-September) and post-monsoon (October-November).

The location (longitude and latitude) and altitude of runoff observation sites are shown in Table 1 and figure 3. The altitude of the hydro-meteorological stations varied from 588 to $2,591 \mathrm{~m}$.

Table 1. Runoff data availability in Satluj River Basin.

\begin{tabular}{|l|l|l|l|}
\hline \multicolumn{1}{|c|}{ Station } & \multicolumn{1}{c|}{ Latitude and longitude } & \multicolumn{1}{c|}{ Elevation (m) } & \multicolumn{1}{c|}{ Time span } \\
\hline Rampur & $31^{\circ} 27^{\prime} 15^{\prime \prime} \& 77^{\circ} 38^{\prime} 40^{\prime \prime}$ & 1,302 & $1984-2010$ \\
\hline Suni & $31^{\circ} 14^{\prime} 15^{\prime \prime} \& 77^{\circ} 06^{\prime} 30^{\prime \prime}$ & 843 & $1984-2010$ \\
\hline Kasol & $31^{\circ} 21^{\prime} 25^{\prime \prime} \& 76^{\circ} 52^{\prime} 42^{\prime \prime}$ & 809 & $1984-2010$ \\
\hline Bhakra & $31^{\circ} 24^{\prime} 53^{\prime \prime} \& 76^{\circ} 25^{\prime} 59^{\prime \prime}$ & 588 & $1984-2010$ \\
\hline Khab & $31^{\circ} 48^{\prime} 30^{\prime \prime} \& 78^{\circ} 41^{\prime} 30^{\prime \prime}$ & 2,591 & $1990-2008$ \\
\hline Nathpa & $31^{\circ} 33^{\prime} 36^{\prime \prime} \& 77^{\circ} 59^{\prime} 24^{\prime \prime}$ & 2,054 & $1990-2008$ \\
\hline
\end{tabular}

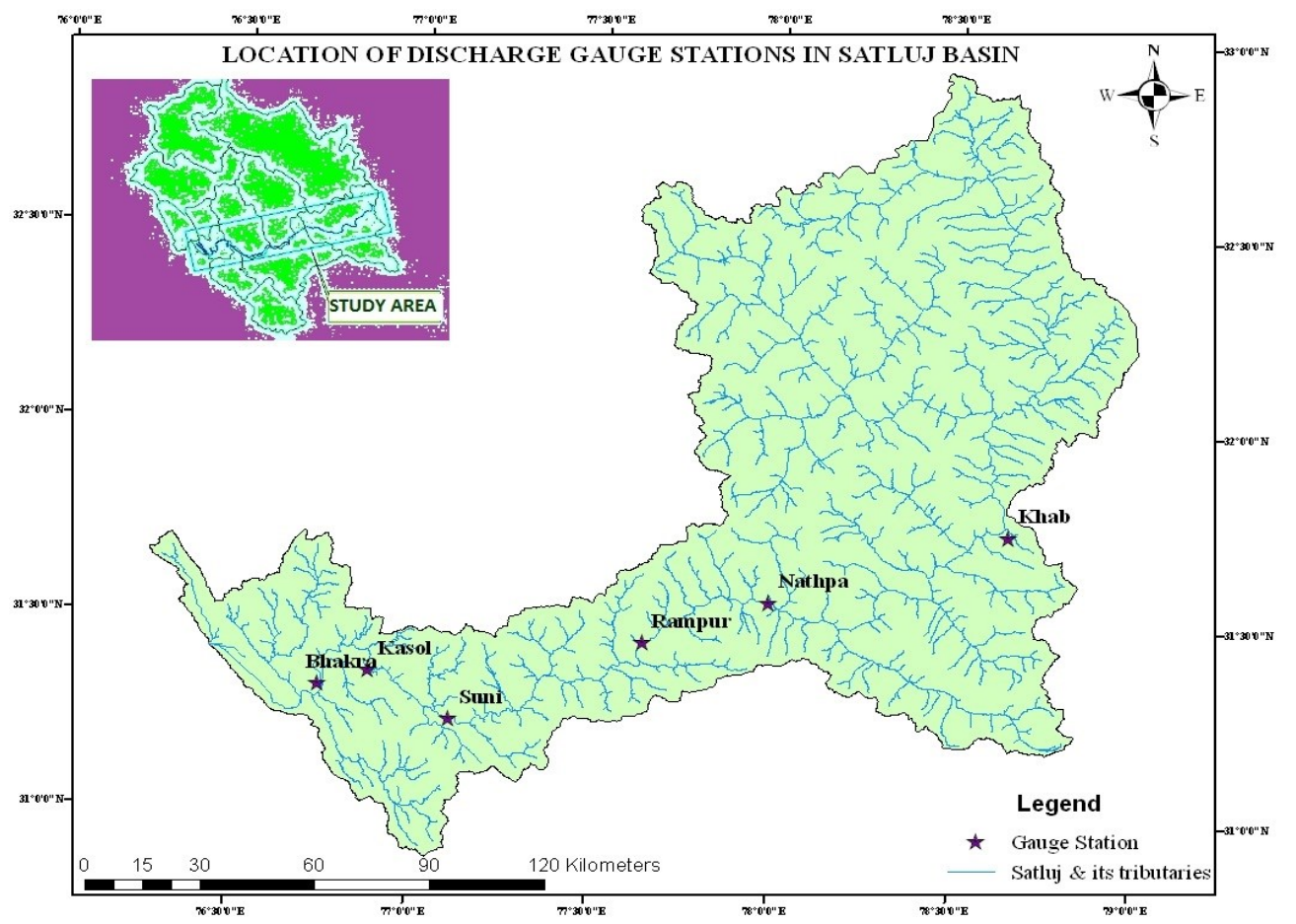

Figure 3. Location of runoff observation sites in Satluj River Basin.

In order to investigate the trends, several statistical techniques are currently available. In the present study, trend analysis have been made by using both non-parametric (Mann-Kendall test) and parametric (linear regression analysis) procedures. Parametric tests assume that the random variable is normally distributed and homo-sedastic (homogeneous variance). Non-parametric tests make no assumption for probability distribution. The purpose of trend analysis is to determine if the values of a random variable generally increase (or decrease) over some period of time in statistical terms (Helsel and Hirsch, 1992).

\subsection{Mann-Kendall test}

The non-parametric tests are more suitable for non-normally distributed, censored data, including missing values which are frequently encountered in hydro-meteorological time series (Hirsch and Slack, 1984; Yue and Pilon, 2004). The Mann-Kendall trend test has therefore been widely used for testing trends in many natural time series that deviate significantly from the Normal distribution, such as temperature. The MK test was found to be an effective tool for identifying trends in hydrologic and other related variables, resistant to the effect of extreme values (Hirsch et al., 1982; Burn, 1994). This test has been applied to temperature, precipitation and stream flow data 
series (Yu et al., 1993; Douglas et al., 2000; Yue et al., 2003; Burn et al., 2004). The MK test applied in this study is a rank based method for evaluating the presence of trends in time series data, without specifying whether the trend is linear or nonlinear.

To identify the trends in the climatic variables with reference to climate change, the nonparametric Mann-Kendall test (Mann, 1945; Kendall, 1975) has been applied in hydrometeorological data. Mann originally used this test and Kendall subsequently derived the test for statistical distribution. The co-variances between Mann-Kendall statistics were proposed by Dietz and Kileen (1981) and the test was extended in order to include seasonality (Hirsch and Slack, 1984). The test compares the relative magnitudes of sample data rather than the data values themselves (Gilbert, 1987). In the present study, test was applied to mean temperature for determining monotonic trends.

The MK test has two parameters i.e. significant level, indicates the trend's strength and the slope magnitude, indicates the direction as well as magnitude of the trend. The data values are evaluated as an ordered time series. Each data value is compared to all subsequent data values. The initial value of the Mann-Kendall statistic, $\mathrm{S}$, is assumed to be 0 (e.g., no trend). If a data value from a later time period is higher than a data value from an earlier time period, $\mathrm{S}$ is incremented by 1 . On the other hand, if the data value from a later time period is lower than a data value sampled earlier, $\mathrm{S}$ is decremented by 1 . The net result of all such increments and decrements yields the final value of $\mathrm{S}$. A very high positive value of $\mathrm{S}$ is an indicator of an increasing trend and a very low negative value indicates a decreasing trend. However, it is necessary to compute the probability associated with $\mathrm{S}$ and the sample size, $\mathrm{n}$, to statistically quantify the significance of the trend. So, the MK test considers only the relative values of all terms in the series $X=\left\{\mathrm{x}_{1}, \mathrm{x}_{2}, \ldots, \mathrm{x}_{\mathrm{n}}\right\}$ to be analysed. The Mann-Kendall statistic $\mathrm{S}$ which is the sum of the differences between the data points is defined as (Salas, 1992)

$$
S=\sum_{i=1}^{N-1} \sum_{j=i+1}^{N} \operatorname{sgn}\left(x_{j}-x_{i}\right)
$$

where $x_{i}$ and $x_{j}$ are the sequential data values and $n$ is the number of data points. Let $x_{j}-x_{i}=\theta$. The value of sign $(\theta)$ is computed as

$$
\operatorname{sgn}(\theta)=\left\{\begin{array}{cll}
1 & \text { if } & \theta>1 \\
0 & \text { if } & \theta=1 \\
-1 & \text { if } & \theta<1
\end{array}\right.
$$

For large samples ( $\mathrm{n}>10)$, the test is conducted using a normal distribution (Helsel and Hirsch, 1992) with mean E(S) and variance Var (S). Kendall (1975) obtained the theoretical mean and variance of $\mathrm{S}$ under the assumption of no trend as:

$$
\begin{gathered}
\mathrm{E}(S)=0 \\
\operatorname{Var}(S)=\frac{1}{18}(N(N-1)(2 N+5) \\
\left.-\sum_{k=1}^{n} t_{k}\left(t_{k}-1\right)\left(2 t_{k}+5\right)\right),
\end{gathered}
$$

where $t_{k}$ is the extent of any given tie (number of $x$ 's involved in a given tie), and $\Sigma t_{k}$ denotes the sum of the terms $t_{k}\left(t_{k}-1\right)\left(2 t_{k}+5\right)$ which are evaluated and summed for each tie of the $t_{k}$ number in the data. The standard normal variable $Z$ is computed by: 


$$
Z=\left\{\begin{array}{ccc}
\frac{S-1}{\sqrt{\operatorname{Var}(S)}} & \text { if } & S>0 \\
0 & \text { if } & S=0 \\
\frac{S+1}{\sqrt{\operatorname{Var}(S)}} & \text { if } & S<0
\end{array}\right.
$$

Compute the probability associated with this normalised test statistic. The trend is said to be decreasing if $\mathrm{Z}$ is negative and the computed probability is greater than the level of significance. If the q-value is less than or equal to the significance level then it is correct to reject the null hypothesis that a trend does not exist in the data set. The trend is said to be increasing if the $\mathrm{Z}$ is positive and the computed probability is greater than the level of significance. If the computed probability is less than the level of significance, there is no trend. If the computed value of $|\mathrm{Z}|>\mathrm{z}$ $\alpha / 2$, the null hypothesis $H_{0}$ of having no trend in the data series is rejected at $\alpha$ level of significance in a two-sided test. Thus, in a two-tailed test for trend, the null hypothesis, that there is no trend in the dataset, is either rejected or accepted depending on whether the calculated $\mathrm{Z}$ statistics is more than or less than the critical value of Z-statistics obtained from the normal distribution table at 5\% significance level. Significance levels ( $p$-values) for each trend test can be obtained as:

$$
p=2[1-\Phi|Z|]
$$

where $\Phi$ denotes the cumulative distribution function (cdf) of a standard normal variant.

\subsection{Pre-Whitney}

However, a basic assumption for the original Mann-Kendall test is that the data should be random and identically distributed which is seldom the case in natural time series. It has been long known (Cox and Stuart, 1955) that positive serial correlation among the observations would increase the chance of a significant answer even in the absence of a trend. The presence of serial correlation can complicate the identification of trends that a positive serial correlation can increase the expected number of false positive outcomes for MK test (Von Storch and Navarra, 1995). So, before applying the MK test, the data series was tested for serial correlation. In order to limit the influence of serial correlation, pre-whitening was proposed by Von Storch (1995). Bayazit and Önöz (2007) suggested that pre-whitening should be avoided when the test has a high power, the slope of trend is high, and the sample size is large (i.e., $\mathrm{n} \geq 50$ ).

In present study, Mann-Kendall test was used in conjunction with the widely used method of pre-whitening. If the lag -1 auto-correlation $r_{1}$ was found to be non-significant at $95 \%$ confidence level, then the MK test was applied directly to the original data series $\mathrm{x}_{1}, \mathrm{x}_{2}, \ldots, \mathrm{x}_{\mathrm{t}}$. Otherwise, the test was applied to the pre-processed data series $\mathrm{x}_{2}-\mathrm{r}_{1} \mathrm{x}_{1}, \mathrm{x}_{3}-\mathrm{r}_{1} \mathrm{x}_{2}, \ldots, \mathrm{x}_{\mathrm{t}}-\mathrm{r}_{1} \mathrm{x}_{\mathrm{t}-1}$ referred to as 'prewhitened' (Von Storch and Navarra, 1995; Partal and Kahya, 2006). The pre-whitening removes serial correlation from the data by means of the following formula:

$$
\mathrm{X}_{\mathrm{t}}^{\prime}=\mathrm{x}_{\mathrm{t}}-\mathrm{r}_{1} \mathrm{x}_{\mathrm{t}-1}
$$

where $x_{t}$ is the original time series value for time interval $t, X_{t}^{\prime}$ is the pre-whitened time series value and $r_{1}$ is the lag -1 autocorrelation coefficient that can be expressed as:

$$
r_{1}=\frac{\frac{1}{n-1} \sum_{t=1}^{n-1}\left[X_{t}-E\left(X_{t}\right)\right]\left[X_{t+1}-E\left(X_{t}\right)\right]}{\frac{1}{n} \sum_{t=1}^{n}\left[X_{t}-E\left(X_{t}\right)\right]^{2}}
$$

where $E\left(x_{t}\right)$ is the mean of the sample data. Von Storch and Navarra (1995) also demonstrated that pre-whitening operation is not necessary for $r_{1} \leq 0.1$.

\subsection{Regression}

The changes in annual and seasonal runoff were plotted against time and the trend was examined by fitting the linear regression line. Linear regression analysis indicates the tendency rate 
(slope) using least squares at the $95 \%$ confidence level, indicates the mean temporal change of the studied variable. Positive values of the slope show increasing trends, while negative values indicate decreasing trends. The total change during the period under observation is obtained by multiplying the slope with the number of years (Tabari and Marofi, 2010; Tabari et al., 2010a, b). The parametric test considers the linear regression of the random variable $\mathrm{Y}$ on $\mathrm{X}$, expressed as:

$$
Y=\beta_{0}+\beta_{1} X+\varepsilon
$$

\section{RESULTS AND DISCUSSION}

The analysis of runoff, annual as well as seasonal, of different observation sites in the basin showed a large variability in the trends and magnitudes. Figures (4-11) and Tables (2-3) show the results of trend analysis of runoff in the winter, pre-monsoon, monsoon and post-monsoon seasons along with mean annual runoff in the river basin.

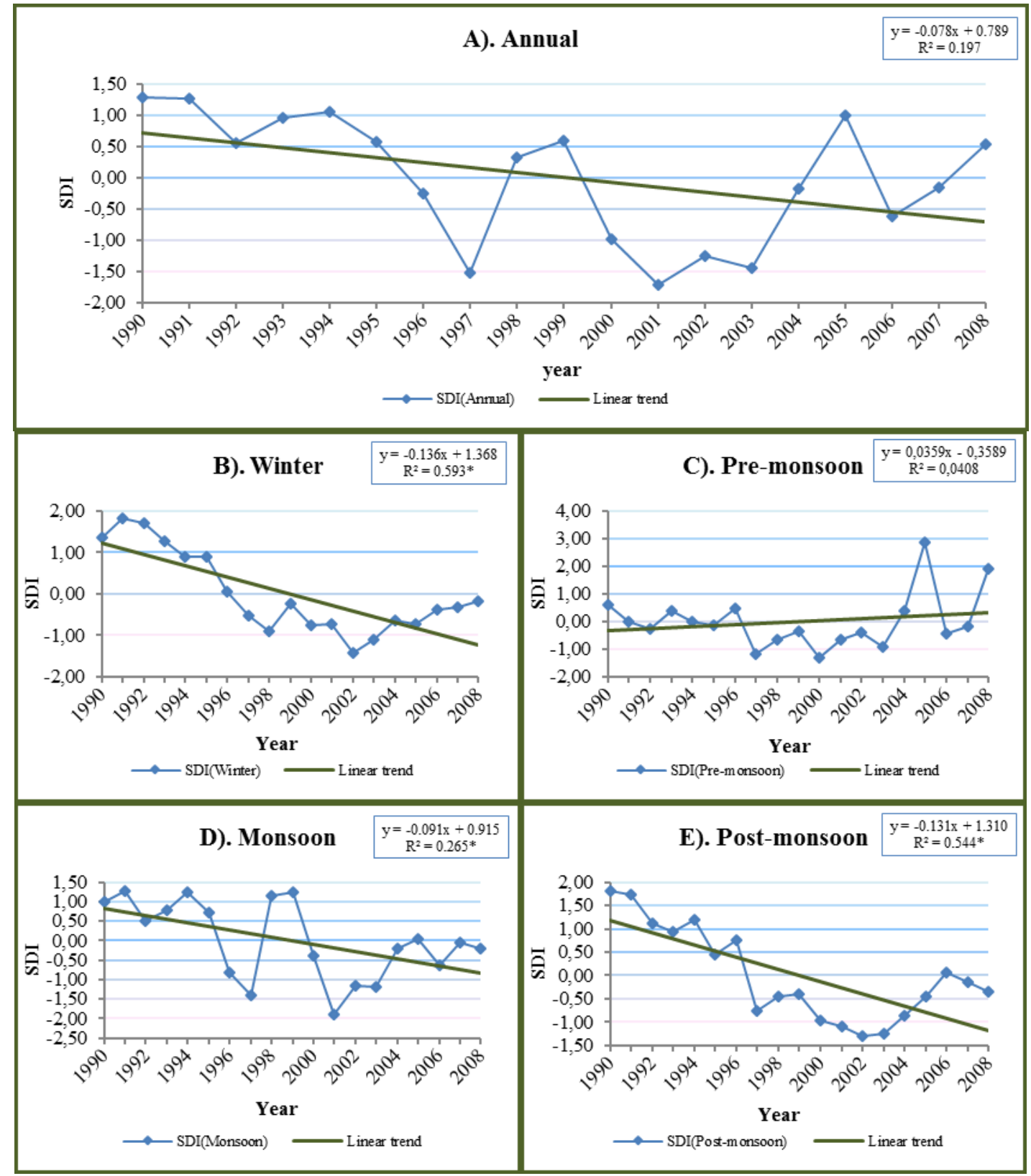

Figure 4. Temporal variations (annual as well as seasonal) and linear trends in average runoff at Khab (Spiti) site of Satluj River (*Significant at 95\% confidence level).

The figure 4 indicates that the annual average runoff has shown decreasing trend but statistically insignificant. Seasonal analysis shows that maximum decreasing trend was observed during winter, followed by post-monsoon and monsoon which are statistically significant. Although 
increasing but statistically insignificant trend was observed during pre-monsoon. The overall analysis shows decreasing trend with episodic fluctuations.

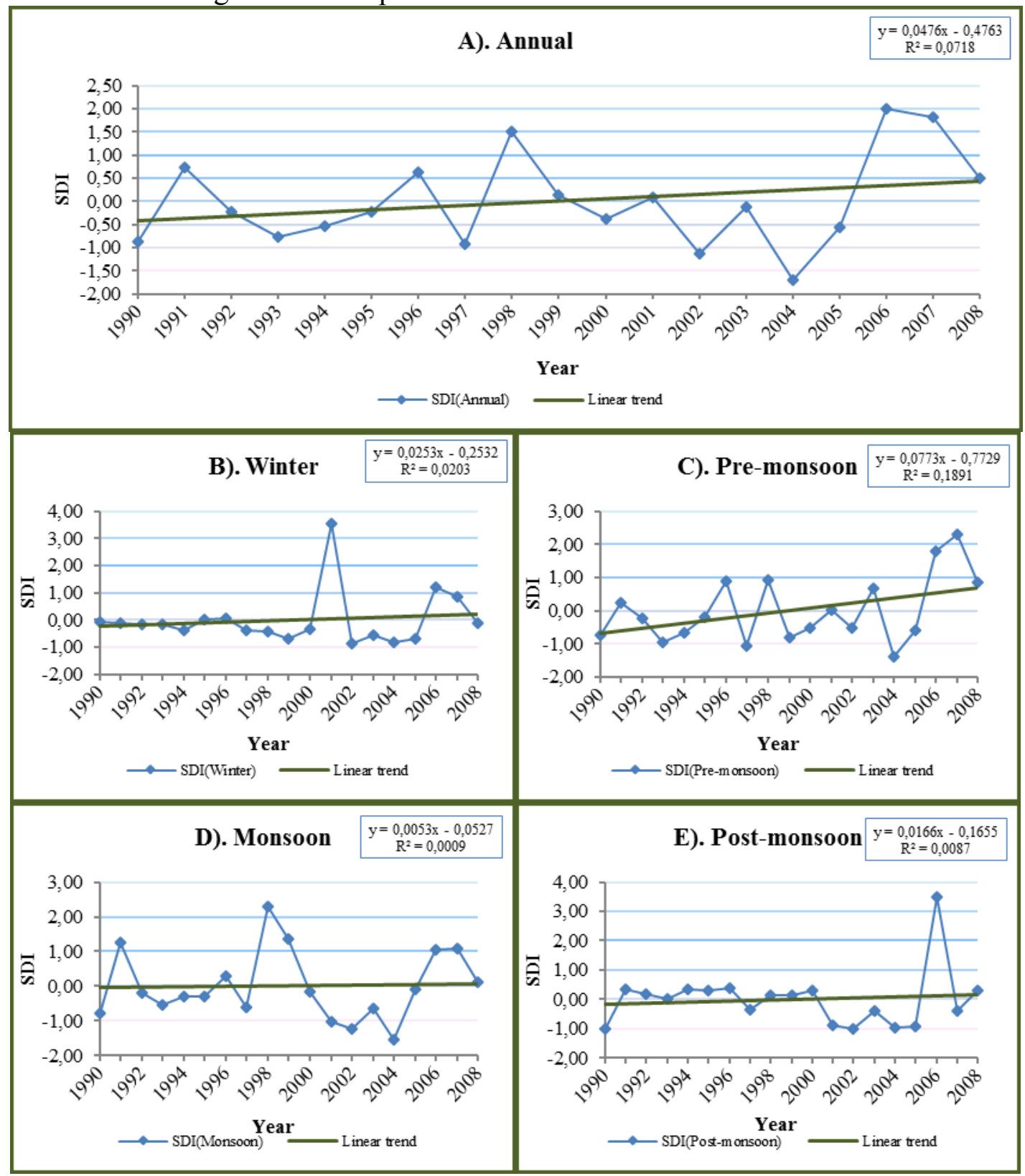

Figure 5. Temporal variations (annual as well seasonal) and linear trends in average runoff at Khab (Satluj) site of Satluj River.

The figure 5 indicates that the annual average runoff has shown increasing trend but statistically insignificant. Seasonal analysis shows that maximum increasing trend was observed during pre-monsoon, followed by winter and post-monsoon which are statistically insignificant. No trend was observed during monsoon season. The overall analysis shows increasing trend with the exception of some periodic behaviour. 


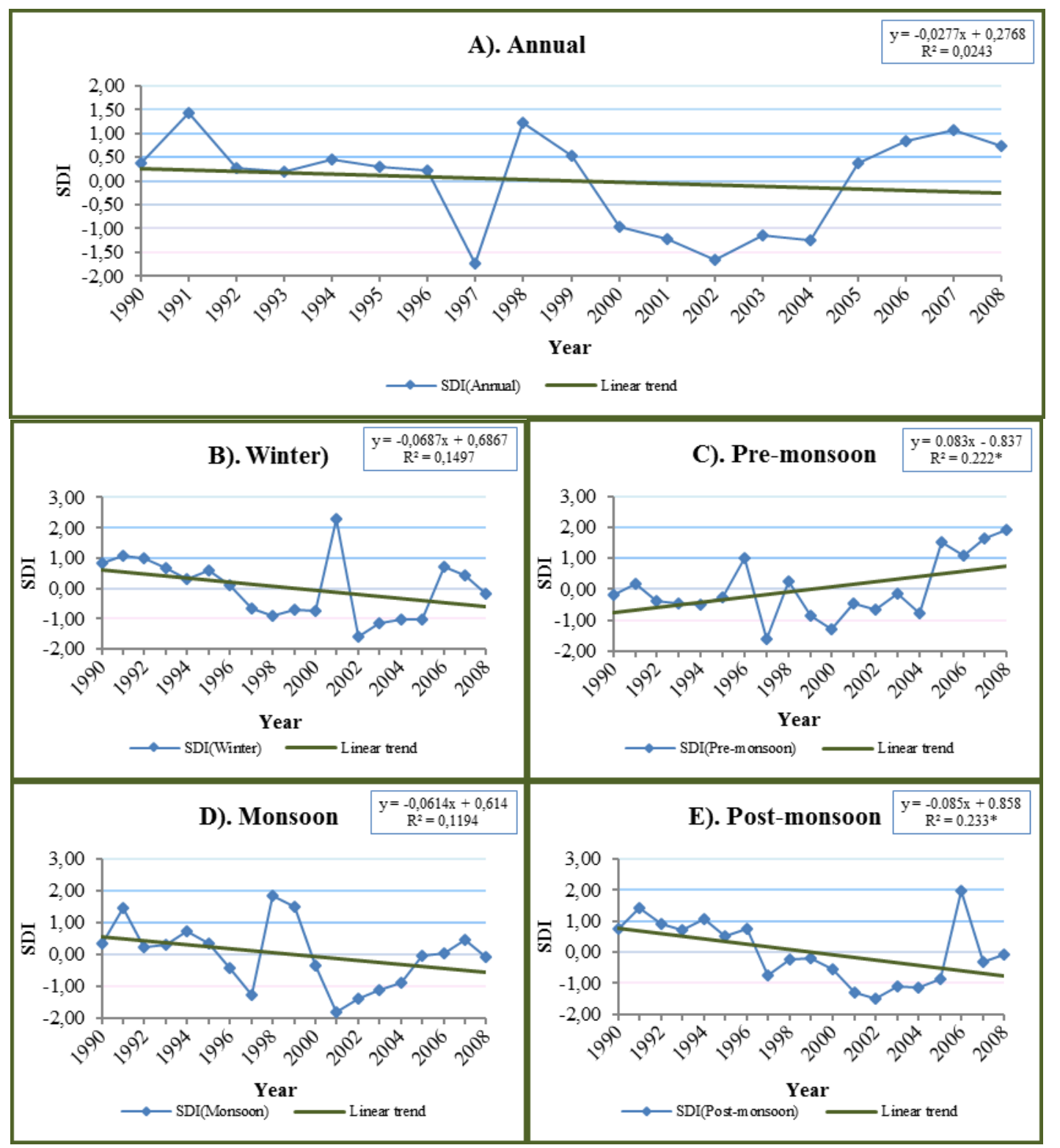

Figure 6. Temporal variations (annual as well as seasonal) and linear trends in average runoff at Khab (Spiti+Satluj) site of Satluj River (*Significant at 95\% confidence level).

The figure 6 indicates that the average annual runoff has shown decreasing but statistically insignificant trend. On the basis of seasonal analysis, maximum decreasing trend was observed during post-monsoon which is statistically significant, followed by winter and monsoon but statistically insignificant. The increasing and also statistically significant trend was observed during pre-monsoon. 


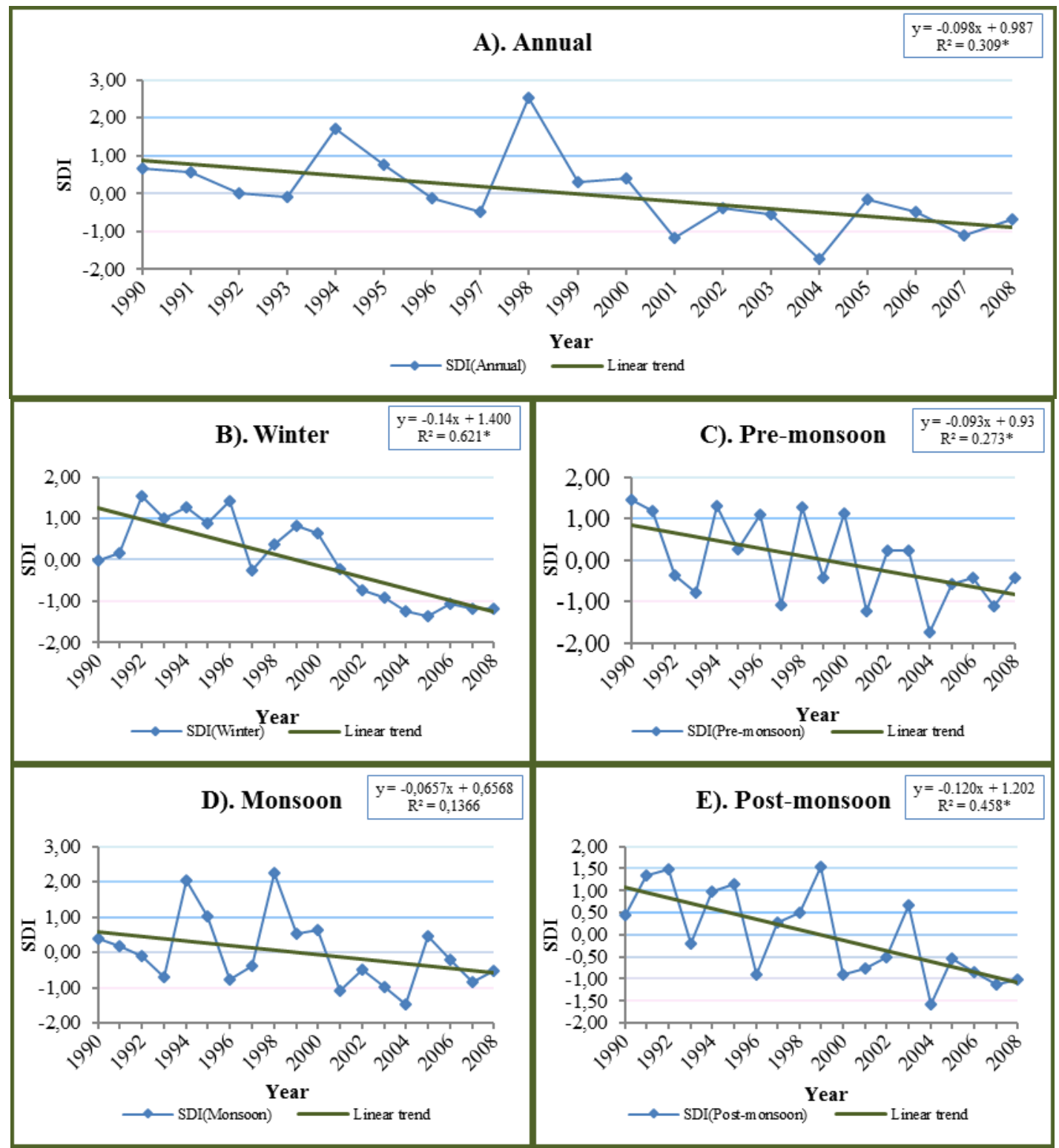

Figure 7. Temporal variations (annual as well as seasonal) and linear trends in average runoff at Nathpa site of Satluj River (*Significant at 95\% confidence level).

The figure 7 indicates that the annual average runoff has shown decreasing trend which is statistically significant. Seasonal analysis shows that the maximum decreasing trend was observed during winter, followed by post-monsoon and pre-monsoon which are statistically significant. The similar decreasing but statistically insignificant trend was observed during monsoon season. 


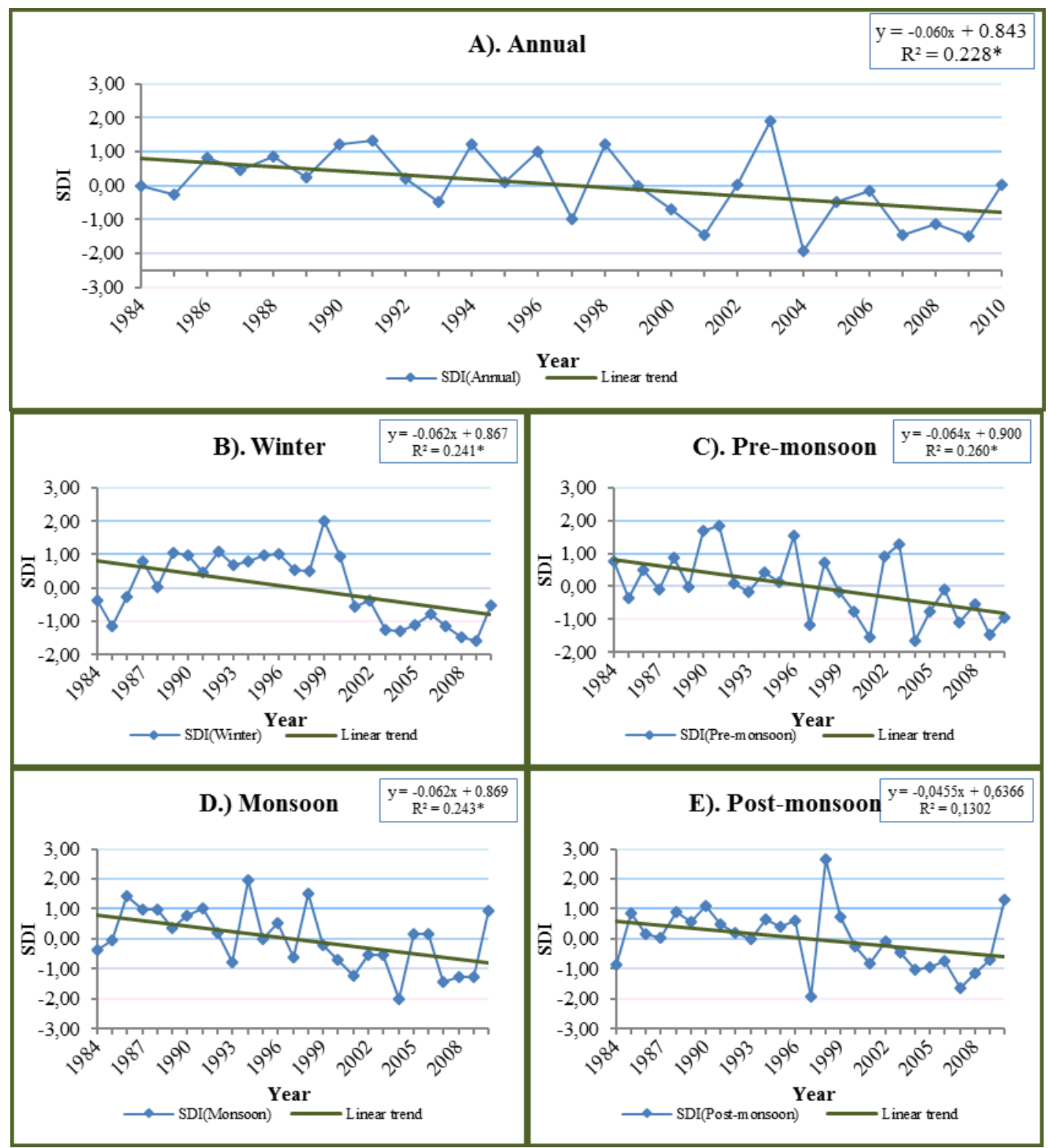

Figure 8. Temporal variations (annual as well as seasonal) and linear trends in average runoff at Rampur site of Satluj River (*Significant at 95\% confidence level).

The figure 8 indicates that the annual average runoff has shown decreasing trend which is statistically significant. Seasonal analysis shows that the maximum decreasing trend was observed during pre-monsoon, followed by monsoon and winter which are statistically significant. The similar decreasing but statistically insignificant trend was observed during post-monsoon season. 


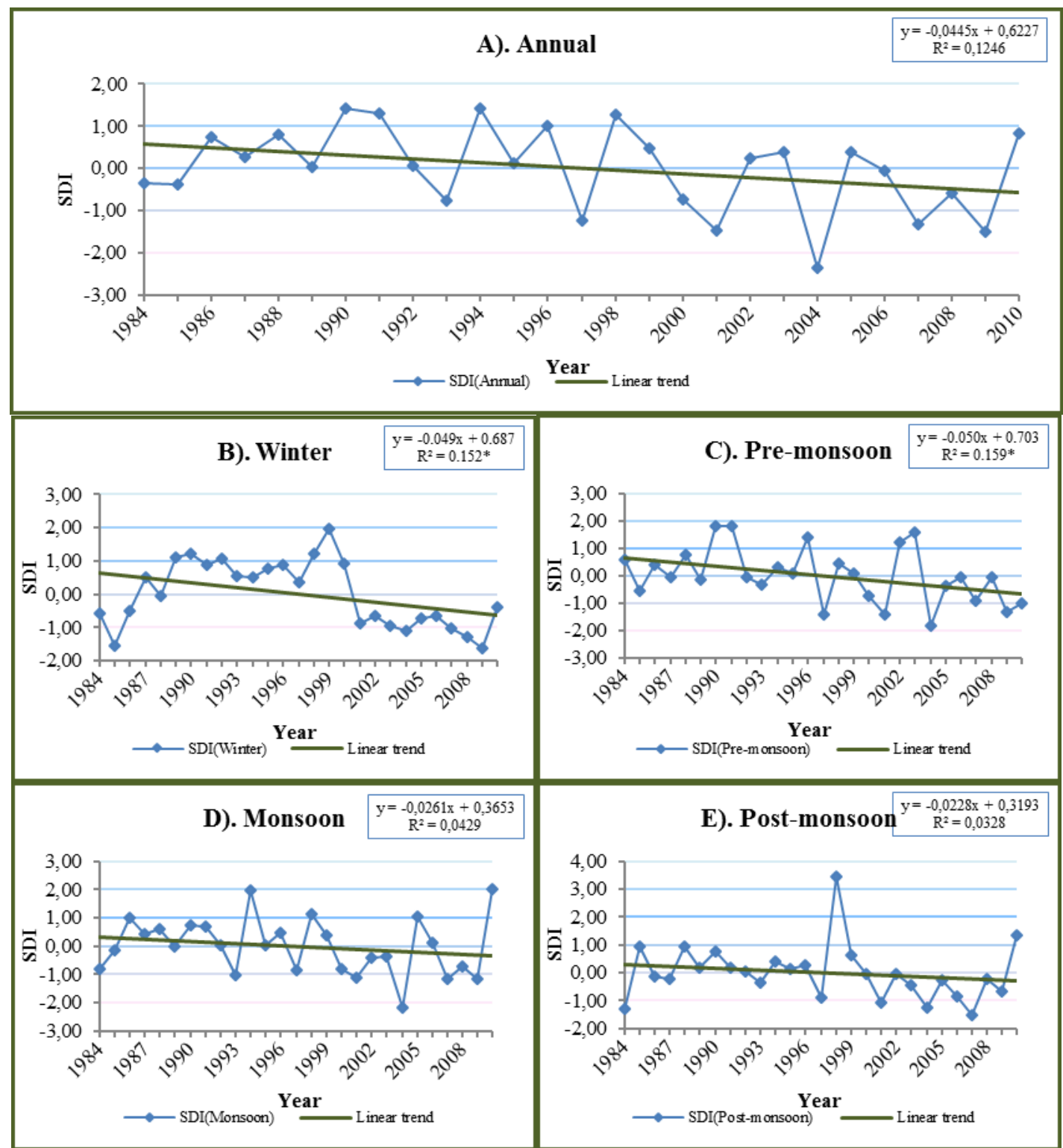

Figure 9. Temporal variation (annual as well as seasonal) and linear trend in average runoff at Suni site of Satluj River (*Significant at 95\% confidence level).

The figure 9 indicates that the average annual runoff has shown decreasing but statistically significant trend. Seasonal analysis shows that the maximum decreasing trend was observed during pre-monsoon, followed by winters which are statistically significant. The similar decreasing but statistically insignificant trend was observed during monsoon, followed by post-monsoon season. 


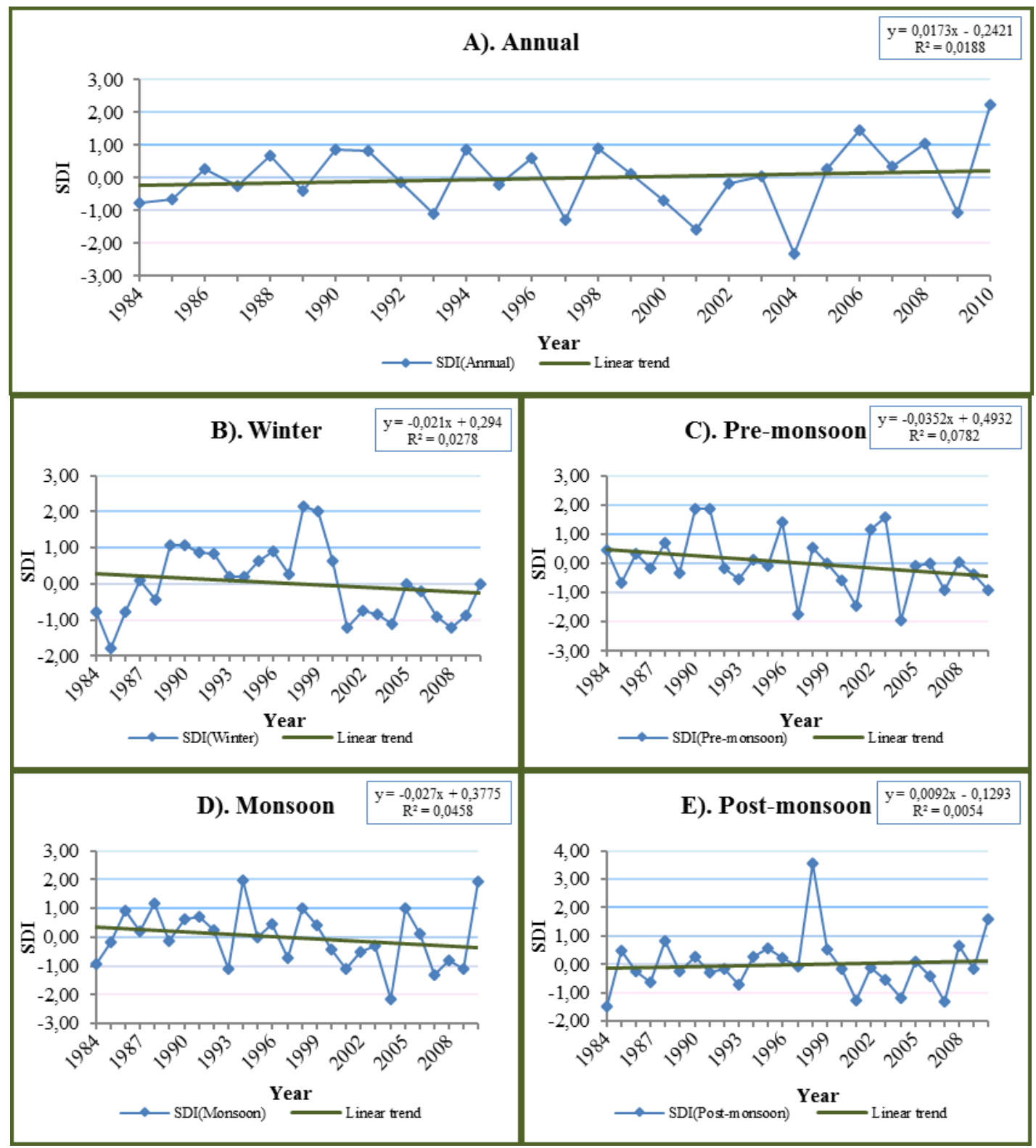

Figure 10. Temporal variations (annual as well as seasonal) and linear trends in average runoff at Kasol site of Satluj River.

The figure 10 indicates that the average annual runoff has shown slightly increasing trend but statistically insignificant. Seasonal analysis shows that decreasing trend was observed during premonsoon, followed by monsoon and winter which are statistically insignificant. Although increasing but statistically insignificant trend was observed during post-monsoon season with the exception of some periodic behaviour. 


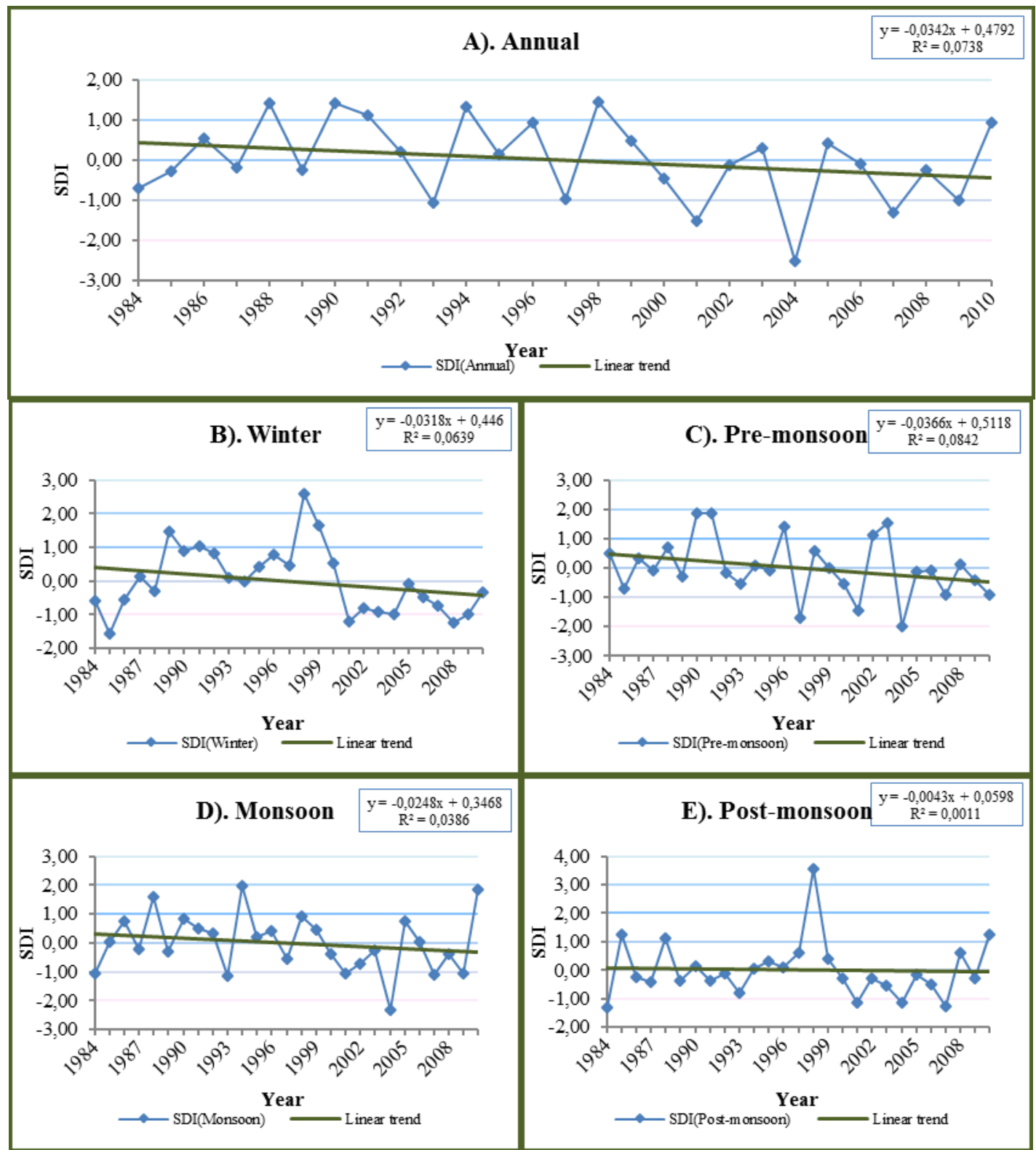

Figure 11. Temporal variations (annual as well as seasonal) and linear trends in average runoff at Bhakra Dam site of Satluj River.

The figure 11 indicates that the annual average runoff has shown decreasing trend which is statistically insignificant. Seasonal analysis shows that the maximum decreasing trend was observed during pre-monsoon, followed by winter, monsoon and post-monsoon but all are statistically insignificant.

Table 2. Results of trend analysis of runoff in Satluj River Basin.

\section{S. No. Station}

Trend analysis

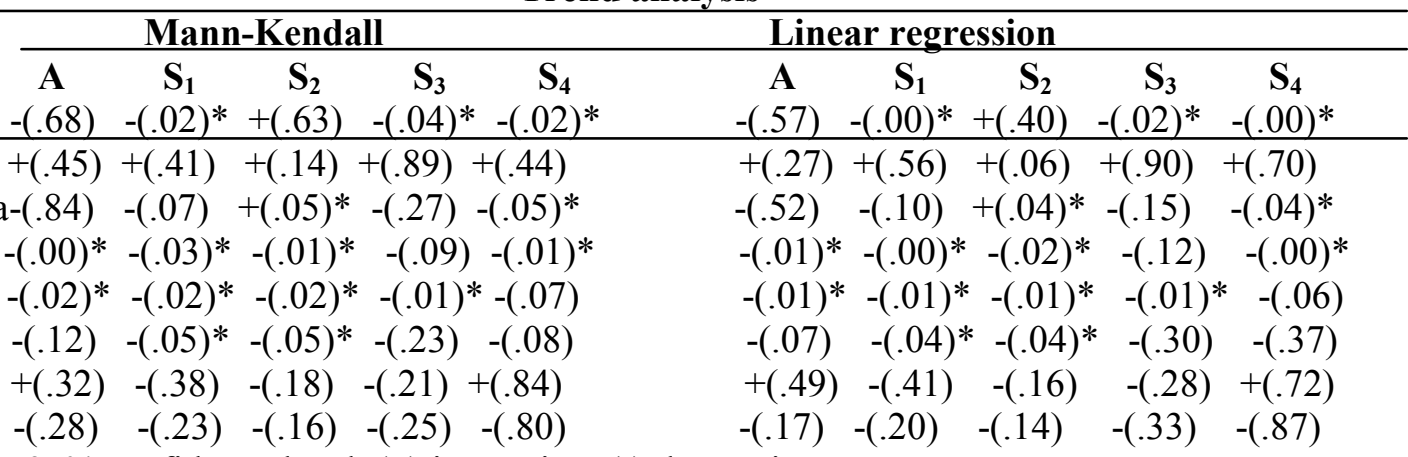

1. Khab Spiti $-(.68)-(.02)^{*}+(.63)-(.04)^{*}-(.02)^{*}$

2. Khab_Satluj $+(.45)+(.41)+(.14)+(.89)+(.44)$

3. Khab_Sp+Sa-(.84) $-(.07)+(.05)^{*}-(.27)-(.05)^{*}$

4. Nathpa $-(.00)^{*}-(.03)^{*}-(.01)^{*}-(.09)-(.01)^{*}$

5. Rampur $\quad-(.02)^{*}-(.02)^{*}-(.02)^{*}-(.01)^{*}-(.07)$

6. Suni $\quad-(.12)-(.05)^{*}-(.05)^{*}-(.23)-(.08)$

7. Kasol $\quad+(.32) \quad-(.38) \quad-(.18) \quad-(.21)+(.84)$

8. Bhakra $\quad-(.28) \quad-(.23) \quad-(.16) \quad-(.25) \quad-(.80)$

$\begin{array}{lllll}-(.17) & -(.20) & -(.14) & -(.33) & -(.87)\end{array}$

*Significance at $95 \%$ confidence level. $(+)$ increasing, (-) decreasing.

A: Annual, $\mathrm{S}_{1}$ : Winter; $\mathrm{S}_{2}$ : Pre-monsoon; $\mathrm{S}_{3}$ : Monsoon; $\mathrm{S}_{4}$ : Post-monsoon 
The trend analysis results (Table 2) of runoff by non-parametric Mann-Kendall and parametric linear regression tests show that the annual runoff at Khab_Satluj and Kasol shows increasing but statistically insignificant trends. Khab_Spiti, Khab_Spiti+Satluj, Nathpa, Rampur, Suni and Bhakra have shown decreasing trends where Nathpa and Rampur are statistically significant at $95 \%$ confidence level. During winter, only Khab_Satluj shows increasing but statistically insignificant trend. Khab_Spiti, Khab_Spiti+Satluj, Nathpa, Rampur, Suni, Kasol and Bhakra show decreasing trends where Khab_Spiti, Nathpa, Rampur and Suni are statistically significant. During pre-monsoon, Khab_Spiti, Khab_Satluj and Khab_Spiti+Satluj have shown increasing trends where Khab_Spiti+Satluj is statistically significant. Nathpa, Rampur, Suni, Kasol and Bhakra show decreasing trends where Nathpa, Rampur and Suni are statistically significant. During monsoon, only Khab_Satluj shows increasing but statistically insignificant trend. Khab_Spiti, Khab_Spiti+Satluj, Nathpa, Rampur, Suni, Kasol and Bhakra show decreasing trends where only Rampur is statistically significant. During post-monsoon, Khab_Satluj and Kasol show increasing but statistically insignificant trend. Khab_Spiti, Khab_Spiti+Satluj, Nathpa, Rampur, Suni and Bhakra show decreasing trends where Khäb_Spiti, Khäb_Spiti+Satluj and Nathpa are statistically significant at $95 \%$ confidence level.

Table 3. Trend test results of runoff.

\begin{tabular}{lccccc}
\hline Seasons & $\begin{array}{c}\text { No. of } \\
\text { trends }\end{array}$ & $\begin{array}{c}\text { No. of increasing } \\
\text { trends (significant) }\end{array}$ & $\begin{array}{c}\text { \% } \\
\text { (sign) }\end{array}$ & $\begin{array}{c}\text { No. of decreasing } \\
\text { trends (significant) }\end{array}$ & $\begin{array}{c}\% \\
\text { (sign) }\end{array}$ \\
\hline Annual & 8 & $2(0)$ & $25(0)$ & $6(2)$ & $75(25)$ \\
Winter & 8 & $1(0)$ & $12.5(0)$ & $7(4)$ & $87.5(50)$ \\
Pre-monsoon & 8 & $3(1)$ & $37.5(12.5)$ & $5(3)$ & $62.5(37.5)$ \\
Monsoon & 8 & $1(0)$ & $12.5(0)$ & $7(2)$ & $87.5(25)$ \\
Post-monsoon & 8 & $2(0)$ & $25(0)$ & $6(3)$ & $75(37.5)$ \\
\hline
\end{tabular}

\# Significance at 95\% confidence level.

Trend analysis results of runoff (Table 3$)$ show that out of 8 annual trends $2(25 \%)$ are statistically insignificant increasing and $6(75 \%)$ are decreasing in nature where $2(25 \%)$ are statistically significant at $95 \%$ confidence level. During winter, only $1(12.5 \%)$ is showing increasing but statistically insignificant. $7(87.5 \%)$ are showing decreasing trends where $4(50 \%)$ are statistically significant. During pre-monsoon, $3(37.5 \%)$ are showing increasing trends but only $1(12.5 \%)$ is statistically significant. $5(62.5 \%)$ are decreasing in nature where $3(37.5 \%)$ are statistically significant. During monsoon, only $1(12.5 \%)$ is showing increasing but statistically insignificant. $7(87.5 \%)$ are showing decreasing trends where $2(25 \%)$ are statistically significant. During post-monsoon, $2(25 \%)$ are showing increasing but statistically insignificant. 6 (75\%) are showing decreasing trends where $3(37.5 \%)$ are statistically significant.

Table 4. Seasonal distribution of the annual runoff of Satluj River at Bhakra Dam (1984-2010).

\begin{tabular}{|l|c|c|}
\hline \multicolumn{1}{|c|}{ Seasons } & $\begin{array}{c}\text { Average runoff } \\
\text { (Cumecs) }\end{array}$ & $\begin{array}{c}\text { Contribution to } \\
\text { annual flow (\%) }\end{array}$ \\
\hline Winter (December-March) & 121.72 & 6.9 \\
\hline Pre-monsoon (April-June) & 492.41 & 27.9 \\
\hline Monsoon (July-September) & 946.01 & 53.6 \\
\hline Post-monsoon (October-November) & 204.90 & 11.6 \\
\hline Annual (December-November) & $\mathbf{1 7 6 5 . 0 5}$ & $\mathbf{1 0 0}$ \\
\hline
\end{tabular}


Based on the annual distribution of 27 years average runoff data, the seasonal distribution is given in Table 4. It was observed that $81.5 \%$ contribution to annual flow of the river at Bhakra Dam is during the pre-monsoon and monsoon seasons because a high contribution from all the sources of runoff is produced during these two seasons.

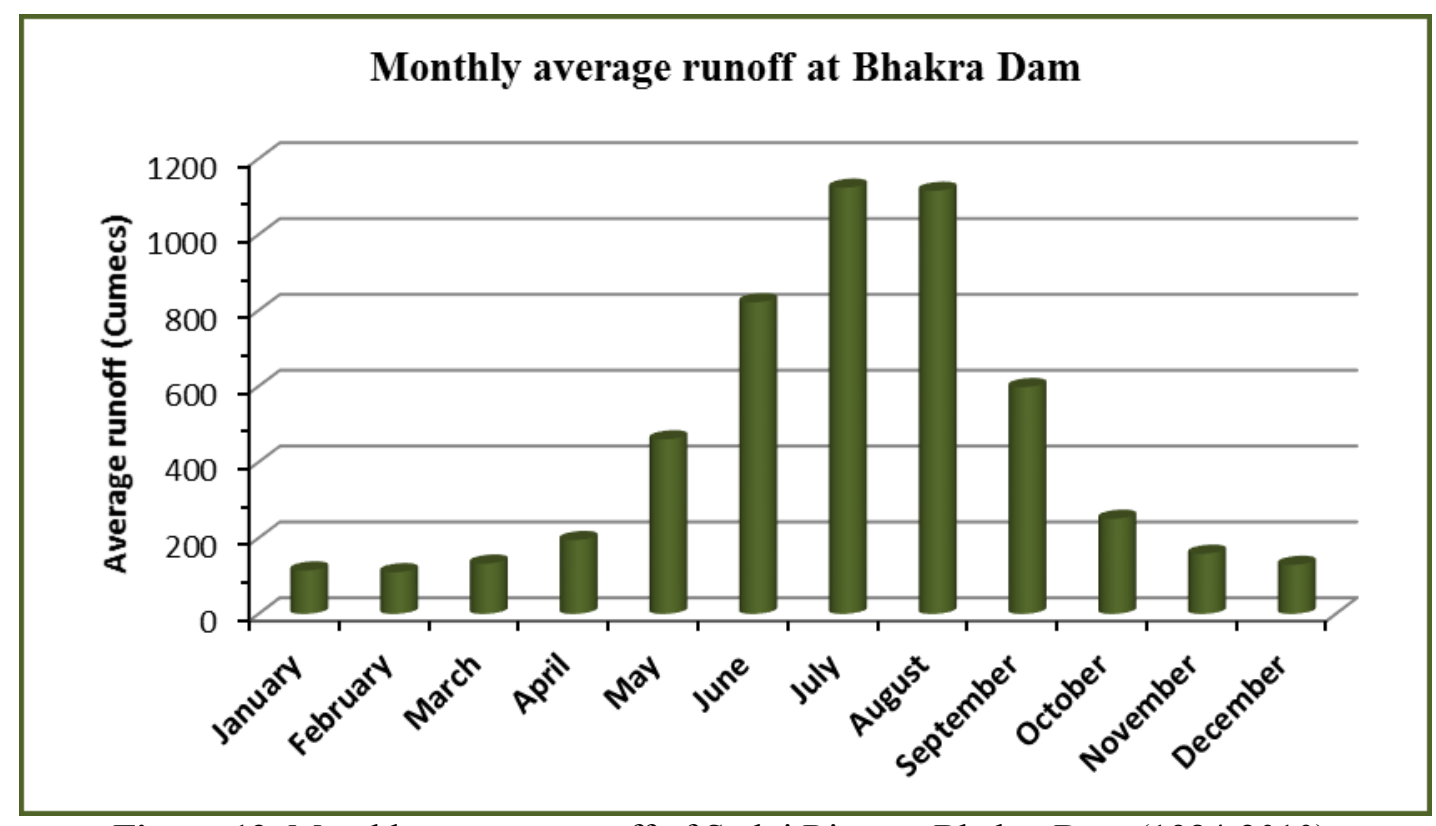

Figure 12. Monthly average runoff of Satluj River at Bhakra Dam (1984-2010).

Based on analysis of 27 years (1984-2010) average runoff data, the monthly distribution of streamflow at Bhakra Dam is shown in Figure 12 and seasonal contribution is given in Table 4. The figure depicts that maximum flow was observed in the month of July, followed by August, resulting due to combined contribution of rainfall and snowmelt. The minimum flow was observed in the month of February.

The results indicate remarkable differences among the observation stations with negative and positive trends. The trends found by the linear regression were almost similar to that of MannKendall test. Majority of observation sites in river basin have experienced decreasing trends in runoff on seasonal and annual scales. Almost half of them were statistically significant at $95 \%$ confidence level. The analysis of runoff for the Satluj River Basin indicates significant changes from 1984 to 2010. In such mountainous region, runoff from snowmelt and glaciermelt provides the dominant contribution to river flows during pre-monsoon apart from rainfall during monsoon season. The uneven distribution of rain, its intensity and periodicity, shows the irregular pattern of runoff at various locations. There may be the time lag in the rainfall and water flow in river. Water flow does not increase just after the rain because rain initially recharges the ground water and after it is saturated, the flow in the river might show increased values with subsequent rains.

The glaciermelt component of runoff in the basin appears to have reached its maximum level around 1990. Because of excessive melting during the pre-1990 period, the glaciers appear to have thinned considerably. Warmer climatic conditions accelerated the melting of snow resulting in faster disappearance of seasonal snow cover from the Satluj Basin (Singh and Bengtsson, 2005). Decreasing runoff, even during winter, despite unusually rising mean temperature and precipitation, corroborates the fact that thinning glaciers are the sole reason behind waning contribution of glacier-melt during this period.

Runoff depends on various factors such as soil permeability, precipitation intensity, land use/land cover, density of vegetation cover, slope, soil texture and antecedent soil moisture content. Depending upon the characteristics of basin and weather conditions, a substantial part of precipitation after experiencing surface evaporation, storage and infiltration into the ground may be change into stream runoff. There is a shift in the timing of runoff that results from changes rainfall, snowfall and snowmelt dynamics due to climate change. Human activities such as water storage by 
reservoirs, diversion of river water, land use change (afforestation, deforestation and change in agricultural practices) and change in land drainage also modify the physical environment. These modifications affect the runoff in the river channel. The sensitivity of runoff variations provides important insight regarding the responses and vulnerability of different areas to climate change. The influence of climate change on hydrologic processes, especially in mountain basins is paramount for understanding, forecasting and mitigating water related hazards.

\section{CONCLUSIONS}

Trend analysis of historical data concluded that the spatial and temporal variations in runoff of Satluj River are due to climate change. There is a clear contrast in the runoff pattern of river between the high altitude mountainous region and the lower reaches where the runoff pattern changes as a result of contribution from rainfall, especially during monsoon season. The analysis indicates episodic fluctuations which may have been caused due to the variations in the precipitation, temperature and snow-glacier melting. It should be recognised that many events in the lower parts of river basins are aggravated by change in land use practices in the upper parts. Information from trend analysis will be useful in the planning, development and management of water resources in the study area. Densification of runoff recording stations will further strengthen the formulation of future strategy for the management of river catchment area.

\section{Acknowledgements}

Authors are thankful to Indian Council of Medical Research (ICMR) and University Grant Commission (UGC), New Delhi for providing financial assistance in the form of research fellowship.

\section{References}

[1] J.C. Adam, A.F. Hamlet, D.P. Lettenmaier (2009) Implications of global climate change for snowmelt hydrology in the twenty-first century, Hydrological Processes, 23: 962-972.

[2] T.P. Barnett, J.C. Adam, D.P. Lettenmaier (2005) Potential impacts of a warming climate on water availability in snow-dominated regions, Nature, 438: 303-309.

[3] S.K. Bartarya, N.S. Virdi, M.P. Sah (1996) Landslide hazards: Some case studies from the Satluj Valley, Himachal Pradesh: Himalayan Geology, 17: 193-207.

[4] M. Bayazit, B. Önöz (2007) To pre-whiten or not to pre-whiten in trend analysis? Hydrological Sciences Journal, 52 (4): 611-624.

[5] T. Beyene, D.P. Lettenmaier, P._Kabat (2010) Hydrologic impacts of climate change on the Nile River Basin: implications of the 2007 IPCC scenarios, Climatic Change, 100 (3-4): 433-461.

[6] M.R. Bhutiyani, V.S. Kale, N.J. Pawar (2008) Changing streamflow patterns in the rivers of northwestern Himalaya: Implications of global warming in the $20^{\text {th }}$ century, Current Science, 95 (5): 618-626.

[7] D.H. Burn (1994) Hydrologic effects of climatic change in West-Central Canada, Journal of Hydrology, 160: 53-70.

[8] D.H. Burn, M.A. Hag Elnur (2002) Detection of hydrologic trends and variability, Journal of Hydrology, 255: 107-122.

[9] D.H. Burn, J.M. Cunderlik, A. Pietroniro (2004) Hydrological trends and variability in the Liard river basin, Hydrological Science Journal, 49: 53-67.

[10] D.R. Cayan, L.G. Riddle, E. Aguado (1993) The influence of temperature and precipitation on seasonal streamflow in California, Water Resources Research, 29: 1127-1140. 
[11] F.H.S. Chiew, P.H. Whetton, T.A. McMohan, A.B. Pittock (1995) Simulation of the impacts of climate change on runoff and soil moisture in Australian catchments, Journal of Hydrology, 167: 212-147.

[12] D.R. Cox, A. Stuart (1955) Some quick sign tests for trend in location and dispersion, Biometrika, 42: 80-95.

[13] E.J. Dietz, T.J. Killeen (1981) A nonparametric multivariate test for monotone trend with pharmaceutical applications, Journal of the American Statistical Association, 76: 169-174.

[14] E.M. Douglas, R.M. Vogel, C.N. Knoll (2000) Trends in flood and low flows in the United States: impact of spatial correlation, Journal of Hydrology, 240: 90-105.

[15] R.O. Gilbert (1987) Statistical methods for environmental pollution monitoring, Van Nostrand Reinhold, New York.

[16] P.H. Gleick, E.L. Chalecki (1999) The impacts of climate changes for water resources of the Colorado and Sacramento-San Joaquin River Basins, Journal of the American Water Resources Association, 35(6): 1429-1441.

[17] V. Gupta, M.P. Sah, N.S. Virdi, S.K. Bartarya (1994) Landslide hazard zonation in the Upper Satluj Valley, District. Kinnaur, Himachal Pradesh, Journal of Himalayan Geology, 4(1): 81-93.

[18] J.P. Hamilton, G.S. Whitelaw, A. Fenech (2001) Mean annual temperature and annual precipitation trends at Canadian biosphere reserves, Environmental Monitoring and Assessment 67: 239-275.

[19] D.R. Helsel, R.M. Hirsch (1992) Statistical Methods in Water Resources, Elsevier, New York.

[20] R.M. Hirsch, J.R. Slack (1984) Non-parametric trend test for seasonal data with serial dependence, Water Resources Research, 20(6): 727-732.

[21] R.M. Hirsch, J.R. Slack, R.A. Smith (1982) Techniques of trend analysis for monthly water quality data, Water Resources Research, 18: 107-121.

[22] I.P.C.C. (2001a) Climate change 2001: Synthesis Report, In: (eds. Watson et al.), Intergovernmental Panel on Climate Change, Cambridge University Press, Cambridge, UK and New York, USA, pp. 398.

[23] I.P.C.C. (2001b) Report: Climate Change-Impacts, Adaptations and Vulnerability, In: (eds. McCarthy JJ, Canziani OF, Leary NA, Dokken DJ, White KS), Intergovernmental Panel on Climate Change, Cambridge University Press, Cambridge, UK and New York, USA.

[24] M.G. Kendall (1975) Rank Correlation Methods, Griffin, London.

[25] M.S. Khattak, M.S. Babel, M. Sharif (2011) Hydro-meteorological trends in the upper Indus River basin in Pakistan, Climate Research, 46: 103-119.

[26] N.Y. Krakauer, I. Fung (2008) Mapping and attribution of change in streamflow in the coterminous United States, Hydrology and Earth System Sciences, 12: 1111-1120.

[27] I. Krasovskaia, L. Gottschalk (2002) River flow regimes in changing climate, Hydrological Sciences Journal, 47 (4): 597-609.

[28] A. Loukas, M.C. Quick (1996) Effect of climate change on hydrologic regime of two climatically different watersheds, Journal of Hydrologic Engineering, 1(2): 77-87.

[29] H.B. Mann (1945) Nonparametric tests against trend, Econometrica 13: 245-259.

[30] G.B. Pant, K. Rupakumar (1997) Climates of South Asia: Behaviour Studies in Climatology, John Wiley, pp. 126-127.

[31] T. Partal, E. Kahya (2006) Trend analysis in Turkish precipitation data, Hydrological Processes, 20: 2011-2026. 
[32] J.D. Salas (1992) Analysis and modeling of hydrologic time series, In: Handbook of Hydrology, Maidment D.R. (ed). McGraw-Hill: New York, 19.1-19.72.

[33] P. Singh, L. Bengtsson (2005) Impact of warmer climate on melt and evaporation for the rainfed, snowfed and glacierfed basins in the Himalayan region, Journal of Hydrology, 300: 140-154.

[34] H. Tabari, S. Marofi (2010) Changes of pan evaporation in the West of Iran, Water Resources Management, doi: 10.1007/s11269-010-9689-6.

[35] H. Tabari, S. Marofi, M. Ahmadi (2010a) Long-term variations of water quality parameters in the Maroon River, Iran, Environmental Monitoring and Assessment, doi: 10.1007/s10661-010$1633-y$.

[36] H. Tabari, S. Marofi, P. Hosseinzadeh Talaee, K. Mohammadi (2010b) Trend analysis of reference evapotranspiration in the western half of Iran, Agricultural and Forest Meteorology, doi: 10.1016/j.agrformet.2010.09.009.

[37] D. Viviroli, D.R. Archer, D. Buytaert, H.J. Fowler, G.W. Greenwood, A.F. Hamlet, Y. Huang, G. Koboltschnig, M.I. Litaor, J.I. L'opez-Moreno, S. Lorentz, B. Sch“adler, K. Schwaiger, M. Vuille, R. Woods (2010) Climate change and mountain water resources: overview and recommendations for research, management and politics, Hydrology and Earth System Sciences, 7: 2829-2895.

[38] H. Von Storch (1995) Misuses of Statistical Analysis in Climate Research, In: Von Storch H and Navarra A (eds.), Analysis of Climate Variability: Applications of Statistical Techniques. Springer-Verlag, Berlin, pp. 11-26.

[39] H. Von Storch, A. Navarra (1995) Analysis of Climate Variability - Applications of Statistical Techniques, Springer-Verlag: New York.

[40] H. Xu, B. Zhou, Y. Song (2011) Impacts of climate change on headstream runoff in the Tarim River Basin, Hydrology Research, 42 (1): 20-29.

[41] K. Xu, J.D. Milliman, H. Xu (2010) Temporal trend of precipitation and runoff in major Chinese Rivers since 1951, Global and Planetary Change, 73: 219-232.

[42] Y.S. Yu, S. Zou, D. Whittemore (1993) Non-parametric trend analysis of water quality data of rivers in Kansas, Journal of Hydrology, 150: 61-80.

[43] S. Yue, P. Pilon (2004) A comparison of the power of the $t$ test, Mann-Kendall and bootstrap tests for trend detection, Hydrological Sciences Journal-des Sciences Hydrologiques, 49(1): 2137.

[44] S. Yue, C. Wang (2004) The Mann-Kendall Test Modified by Effective Sample Size to Detect Trend in Serially Correlated Hydrological Series, Water Resources Management, 18: 201-218.

[45] S. Yue, P. Pilon, B. Phinney (2003) Canadian streamflow trend detection: impacts of serial and cross-correlation, Hydrological Science Journal, 48: 51-63.

[46] X. Zhang, K.D. Harvey, W.D. Hogg, T.R. Yuzyk (2001) Trends in Canadian streamflow, Water Resources Research, 37(4): 987-998. 